\title{
Status of Water Supply and Sanitation Infrastructure in Opole County (Lubelskie Voivodeship, Poland)
}

\author{
Magdalena Gizińska-Górna' \\ ${ }^{1}$ Department of Environmental Engineering and Geodesy, University of Life Sciences in Lublin, \\ ul. Leszczyńskiego 7, 20-069 Lublin, Poland \\ e-mail: magdalena.gizinska-gorna@up.lublin.pl
}

\begin{abstract}
The paper discusses the status of water supply and sanitation infrastructure in Opole County (poviat) on the basis of results of a survey conducted in 2016 and official statistical data. Opole County is located in the northwestern part of the Lubelskie Voivodeship, Poland, and covers an area of $810 \mathrm{~km}^{2}$. It comprises five rural communes: Chodel, Józefów nad Wisłą, Karczmiska, Łaziska and Wilków, and two urban-rural communes: Opole Lubelskie and Poniatowa. On average, $89.5 \%$ of the County's inhabitants have access to a mains water supply network, but only $32.8 \%$ are connected to a centralized sewerage system. In almost all of the County's communes, there is a disproportion in coverage between the water supply and sewerage networks. The water supply coverage for the individual communes ranges between 88.9-99.6\%, while the sanitation coverage level does not exceed 20\%. One exception is the commune of Poniatowa, where the disproportion is negligible, with $87.7 \%$ of the inhabitants having access to running water and $73.3 \%$ to sanitation services. In 2016, Opole County had eight centralized wastewater treatment plants with a total capacity of approximately $8,470 \mathrm{~m}^{3} / \mathrm{d}$. According to the survey data, there were 6,946 cesspools in the County in 2016. In the future, they should be replaced with highly efficient domestic wastewater treatment plants. In 2016, there were 84 on-site domestic wastewater treatment plants in Opole County. However, they were all systems with a drainfield, a technology that poses a huge threat to the soil and water environments. The present study shows there is a great need for investment in expanding the sanitation infrastructure and replacing the existing cesspools.
\end{abstract}

Keywords: sanitation infrastructure; water supply system; sewerage system; wastewater treatment plant; cesspool

\section{INTRODUCTION}

One of the main factors that determine proper functioning and development of settlements is the level of development of their utility infrastructure (Obarska Pempkowiak et al. 2015; Pawełek 2016). The level of provision of infrastructure affects the quality of life of residents, but also has an impact on the direction and pace of development of local economies. At the same time, the development of infrastructure has an influence on the quality of the natural environment. Two basic elements of utility infrastructure are the water supply and sewerage systems, which are designed to provide all residents in a given area with adequate sanitation and living conditions.
It is important that the water supply and sewerage networks are continuously expanded, if only because of the constantly changing size and age structure of the population, constant development of entrepreneurship, as well as the development of other functions related to land development. An important factor that has spurred the development of water supply and sanitation networks in Poland in the recent years has been the accession to the European Union. As an EU member state, Poland is required to harmonize its law with that of the EU, including regulations regarding utility infrastructure. In the Accession Treaty, Poland committed itself to equipping agglomerations of less than 2,000 Population Equivalent (PE) with centralized wastewater treatment plants and 
sewerage systems, as well as to improve the quality of mains drinking water. In addition, the provisions of the Water Framework Directive have been transposed to national law, mainly through the Water Law Act with executive orders, the Act on Collective Water Supply and Collective Sewerage Piping, and the Environmental Protection Act. One of the basic principles set out in the Water Law Act is that problems related to the supply of potable water to people and the disposal and treatment of wastewater should be handled concurrently (Journal of Laws of the Republic of Poland 2001 No. 115 item 1229). This applies above all to rural areas, where water supply and sanitation infrastructure coverage levels differ vastly from one location to another. Wastewater from these areas can be discharged to a centralized sewerage system, treated in on-site domestic wastewater treatment plants or collected in watertight tanks and systematically transported by gully emptiers to a collective wastewater treatment plant (Chmielowski 2016; Obarska-Pempkowiak et al. 2015). There are many factors that determine which wastewater treatment option will be used in a given area. One of them is the density of development, which affects the possibility of building a sewerage network. Other factors that influence the development of utility infrastructure include topography, investment and operating costs, type of building development, land slopes, and hydrogeological and hydrological conditions (Karolińczak et al. 2015). When analyzing the development of the sanitation system in Poland, one notices a clear increase in the number of users. In $2002,56.7 \%$ of the population was connected to sewers, a figure that increased to $69.6 \%$ in 2015. In rural areas, the number of users of the sanitation system grew from 2 million 78.5 thousand to 5 million 988 thousand people in the years 2002-2015, which was a $188 \%$ increase (Pawełek 2016). However, despite considerable development, the size of the sewerage network in relation to the demand is still very small. In rural areas, especially those with a highly dispersed development pattern, the quantity and quality of sanitation infrastructure can be improved by constructing on-site domestic wastewater treatment plants (Bogusz et al. 2020; Jóźwiakowski et al. 2018; Jóźwiakowski et al. 2017; Micek et al. 2018). In the years 2006-2015, the number of on-site treatment plants in Poland increased by $476 \%$. An on-site domestic wastewater treatment plant is an umbrella term for a variety of technological and technical solutions used to treat domestic wastewater to the required quality level (Chmielowski 2016). The efficiency of such small sewage disposal systems is a key challenge. Meanwhile, under the current legal regulations regarding the construction of on-site domestic wastewater treatment plants, the principal criterion for selecting a wastewater treatment technology is the cost of purchase and assembly of a treatment installation. As a result, most of the the existing on-site domestic wastewater treatment plants in Poland are the cheapest type of treatment plant, i.e systems with a drainfield (Bogusz et al. 2020; Jóźwiakowski et al. 2018; Jóźwiakowski et al. 2017; Micek et al. 2018). Many authors believe that systems with a soakaway drainfield area pose a serious threat to the quality of surface waters and groundwater, and should not be used as stand-alone wastewater treatment installations, but only as a treatment step, to discharge biologically treated wastewater into the ground (Walczowski 2013; Jóźwiakowski 2012; Bugajski et al. 2017; Jucherski and Walczowski 2001). A longterm study by Jóźwiakowski (2003) shows that systems with a drainfield provide very low treatment efficiencies, with maximum removal rates of $40 \%$ for total suspended solids and $38 \%$ for $\mathrm{BOD}_{5}$ and COD.

The present article discusses the status of water supply and sanitation infrastructure in Opole County (poviat), Poland, based on survey data obtained in 2016 and data from the Central Statistical Office (GUS). The survey identified the percentage of the population connected to mains water supply and sanitation systems, the number of cesspools and the numbers of centralized and off-mains domestic wastewater treatment plants.

\section{CHARACTERISTICS OF OPOLE COUNTY}

Opole County is situated in eastern Poland, in the north-west of the Lubelskie Voivodeship (aka Lublin Province) (Fig. 1), and covers an area of $810 \mathrm{~km}$. It has a population of 60,764 people, with a mean population density of 75 people $/ \mathrm{km}^{2}$ (GUS 2016). Opole County borders Lublin County to the east, Puławy County to the north, and Kraśnik County to the south. In the west, it borders two neighbouring voivodeships. To the north-west, it is bounded by the Counties of Zwolen and Lipsko, which are part of the Mazowieckie Voivodeship, and to the south-west it borders Opatów County, 


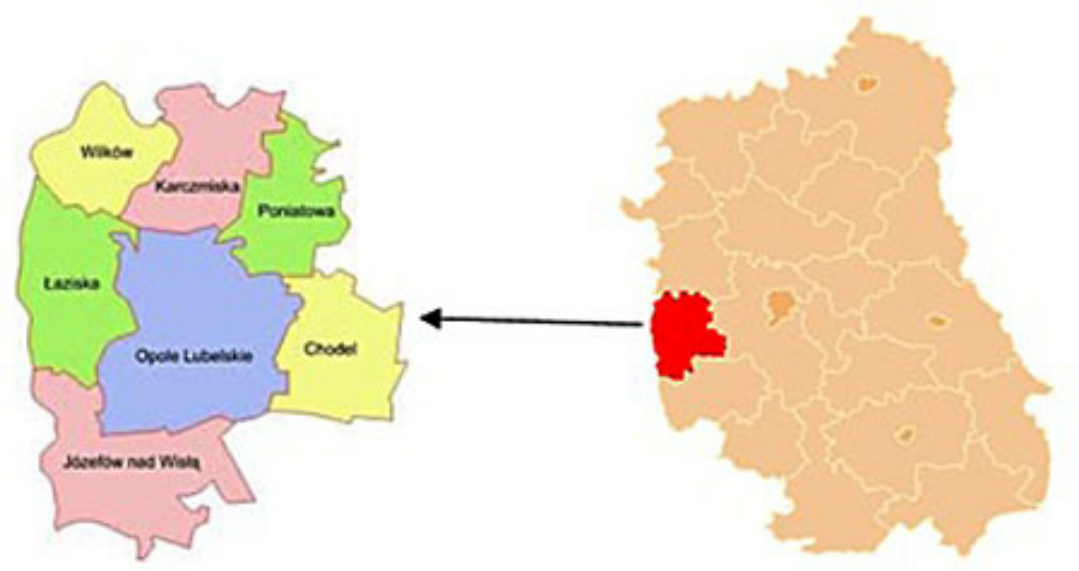

Figure 1. Map of the Lublin Province featuring the Opole Lubelskie County and its communes (www.portalgospodarczy.eurzad.eu)

located in the Świętokrzyskie Voivodeship (Milczarek et al. 2016). The economy of Opole County is mainly based on locally sourced raw materials and natural assets. The dominant industries are crop processing and tourism. Both the low level of industrialization of the County and commitment to the principles of sustainable development pushed the economic development of this area in two directions. A first of these directions is the development of companies in the services and production sectors, and a second is the development of tourism based on natural resources and active leisure services.

Opole County is a typically agricultural area. The crop processing industry is the main branch of economy here. The county boasts several large vegetable, fruit and hop processing companies. Opole County comprises five rural communes: Chodel, Józefów nad Wisłą, Karczmiska, Łaziska, and Wilków, and two urban-rural communes: Opole Lubelskie and Poniatowa (Fig. 1). The administrative seat of Opole County is the town of Opole Lubelskie.

The commune of Chodel is an agricultural commune located in the south-eastern part of the County. The commune has a population of 6,682 inhabitants, who mainly live off farming. It occupies an area of $108.2 \mathrm{~km}^{2}, 80 \%$ of which is arable land and $15 \%$ is forest land. The attractive natural environment of the valley of the river $\mathrm{Ch}$ odel is protected as part of the Chodel Protected Landscape Area (Chodelski Obszar Chronionego Krajobrazu). The commune's soils are predominantly medium quality soils, with almost half of them in the 4th soil valuation class. Fruit farming has a dominant position in local agriculture. Most agricultural holdings are small farms with an area from 5 ha to 10 ha. Interesting historical monuments, attractive recreational areas with a beautiful artificial lake, and a good transport infrastructure create opportunities for the development of tourism (Milczarek et al. 2016).

The commune of Józefów nad Wisłą is situated upon the central Vistula, in the southwestern part of Opole County. It occupies an area of $141 \mathrm{~km}^{2}$ and has 6,721 inhabitants, residing in 34 villages. The commune of Józefów can be called the "Land of Orchards" as orchards occupy 2,000 ha of its area and produce about $60,000 \mathrm{t}$ of fruit each year. Horticulture and vegetable farming are also important industries in this area. Yearly, 2,000 $\mathrm{t}$ raspberries, 500,000 $\mathrm{t}$ strawberries and $2,500 \mathrm{t}$ vegetables, such as cucumbers, onions and cabbage are produced in the commune. Here, the Vistula has created a picturesque valley with characteristic limestone slopes and sandy shores. In the vicinity of Józefów, the river is fed by three tributaries: the rivers Wyżnica, Potok Wrzelowiecki, and Kamienna. Part of the commune's land

Table 1. Area and population of the communes of Opole County

\begin{tabular}{|c|l|c|c|c|}
\hline No. & Commune & $\begin{array}{c}\text { Commune } \\
\text { type }\end{array}$ & Area $\left(\mathrm{km}^{2}\right)$ & $\begin{array}{c}\text { Total } \\
\text { population }\end{array}$ \\
\hline 1 & $\begin{array}{l}\text { Opole } \\
\text { Lubelskie }\end{array}$ & Urban & 194 & 14507 \\
\hline 2 & Poniatowa & Urban & 85 & 14527 \\
\hline 3 & Chodel & Rural & 108.2 & 6682 \\
\hline 4 & $\begin{array}{l}\text { Józefów } \\
\text { nad Wisłą }\end{array}$ & Rural & 141 & 6721 \\
\hline 5 & Karczmiska & Rural & 95 & 5674 \\
\hline 6 & Łaziska & Rural & 109 & 4969 \\
\hline 7 & Wilków & Rural & 78 & 4506 \\
\hline
\end{tabular}

[Based on Central Statistical Office's Local Data Bank (BDL GUS) data for 2016] 
is a protected area known as the Wrzelowiec Landscape Park (Milczarek et al. 2016).

The commune of Karczmiska is situated in the north-west part of the County, at the junction of three subregions: The Nałęczów Plateau (Płaskowyz Nałęczowski), the Bełżyce Plain (Równina Betżycka) and the Chodel Valley (Kotlina Chodelska). The commune covers an area of $95 \mathrm{~km}^{2}$ and has a population of 5,674 inhabitants living in 18 villages. The commune's economy is based mainly on agriculture. The main crops are cereals, root crops, tobacco, raspberries, currants, and strawberries, which grow well on the commune's medium-quality soils. The landscape and climate of the commune, the vicinity of the picturesque towns of Kazimierz Dolny and Nałęczów (a spa), and the location within the borders of the Kazimierz Landscape Park (Kazimierski Park Krajobrazowy) and in its buffer zone, all favour the development of tourism and leisure services, which are gaining in importance in this area (Milczarek et al. 2016).

The commune of Laziska is located in the central part of Opole County and occupies an area of $109 \mathrm{~km}^{2}$. It is divided into 24 villages with 4,969 inhabitants. In the north, it is bounded by the valley of the river Vistula. The whole commune is a protected landscape area. Part of the commune is situated in the Chodel Protected Landscape Area and the remaining part is a fragment of the Wrzelowiec Landscape Park. The commune's economy is agriculture-based (Milczarek et al. 2016).

The commune of Wilków is situated on the gorge of the Vistula (one of the most beautiful gorges along the entire course of the river), on the border between the Bełżyce Plain and the Chodel Valley, along the road connecting the town of Kazimierz Dolny with Opole Lubelskie, south of Kazimierz Dolny. It occupies an area of $78 \mathrm{~km}^{2}$. A characteristic feature of the commune is that it forms a network of dispersed settlements consisting of 26 villages. The commune's population is 4,506 . The entire area of the commune falls within the system of protected areas of the Lubelskie Voivodeship, as part of the Kazimierz Landscape Park, its buffer zone, and the Chodel Protected Landscape Area (Milczarek et al. 2016).

The commune of Opole Lubelskie lies in the western part of the Lubelskie Voivodeship. It is the administrative seat of Opole County and is located in the catchment area of the river Chodelka in the Chodel Valley. The southern part of the commune is located in the Wrzelowiec Landscape Park, and the eastern part belongs to the Chodel Protected Landscape Area. The commune covers an area of $194 \mathrm{~km}^{2}$ and has a population of 17,507 inhabitants residing in 43 villages (Milczarek et al. 2016).

The commune of Poniatowa is situated $40 \mathrm{~km}$ southwest of Lublin, in the eastern part of Opole County. It is located in the forests of the western edge of the Chodel Valley. Part of the town and commune of Poniatowa lies within the Chodel Protected Landscape Area. It consists of 20 villages covering an area of $85 \mathrm{~km}^{2}$. The commune has 14,527 inhabitants (Milczarek et al. 2016).

The use of the County's waters is subject to the provisions of the Vistula River Basin Management Plan of October 18, 2016 and the Regulation of the Regional Director of the Water Management Board in Warsaw on the conditions of using the waters of the Central Vistula water region. The Regulation has been issued to ensure good status or good potential of the region's waters. It lays down requirements for the quality of surface waters, morphological continuity of watercourses, groundwater abstraction, and maintaining an intact flow regime. These requirements are geared towards meeting the environmental objectives set out in the Water Management Plan for surface water bodies and groundwater bodies.

The southern part of the County, which encompasses the catchment area of the river Wyżnica, is characterized a by a low river density, while the central and northern parts, which lie within the catchment area of the river Chodelka have the densest river network in the entire Lublin Upland (Wyżyna Lubelska). In total, the County has 20 natural watercourses with a total length of about $236 \mathrm{~km}$. These include the rivers Chodelka, Chodlik, Ciek Wronów, Jankówka, Jankówka Górna, Jaworzanka, Karczmianka, Kowalanka, Kożuchówka, Kraczewianka, Martwica, Podlipie, Poniatówka, Stara Rzeka, Wisełka, Wrzelówka, Wrzelowianka, Wyżnica, and Zimowa Rzeka. Among them, the river Chodelka is assigned to water quality class III, and the rivers Janówka, Karczmianka and Wyżlica are designated class IV. Of the County's 17 surface water bodies, the general condition of ten is poor and at risk of not meeting environmental objectives, while the status of the remaining seven has been evaluated as good (Milczarek et al. 2016). According to the Vistula River Basin Management Plan, 
the basic factors affecting the quality of surface waters are point-source and area-source releases, mainly municipal and industrial wastewater and pollution from agriculture (arable lands constitute $64.2 \%$ of the basin area of the Vistula) (Journal of Laws of the Republic of Poland 2016 item 1911). Other anthropogenic pressures that pose a threat to water quality include leachate from uninsulated landfills and discharges of originating waters.

The occurrence and distribution of groundwater in Opole County depends on the geological structure and topography of the area. The most diverse conditions of occurrence of groundwater are found in the northern and southern parts of the County. Groundwater in those areas is mainly rock water originating from a fissured layered Cretaceous aquifer. On plateaux, groundwater is manly found in Quaternary rocks. The central part of the County, with the river Chodelka as its hydrological axis, has one continuous groundwater table which connects the hydraulically linked Cretaceous, Quaternary and Alluvial aquifers. The County's main groundwater reservoir and also one that contains the largest volume of water is the Cretaceous aquifer. It is composed of cracked chalky and limestone marls and silica carbonate (opoka) rocks. The aquifer is replenished by precipitation. Because sites with shallow-lying cracked chalk rocks covered with detritus or sandy deposits provide good infiltration (soaking) conditions, these waters are particularly exposed to pollution from surface sources. The main problem related to water management in Opole County is the insufficiently good quality of surface waters, resulting mainly from pollution of the aquatic environment with municipal sewage discharges and runoff of fertilizers from fields.

\section{RESULTS AND DISCUSSION}

The status of the water supply and sanitation infrastructure in Opole County was determined on the basis of the results of a survey carried out in the Lubelskie Voivodeship in 2016. The survey data included information on the lengths of the water supply and sewerage networks in the individual communes, number and capacity of centralized wastewater treatment plants of over $5 \mathrm{~m}^{3} \cdot \mathrm{d}-1$, and number of on-site domestic wastewater treatment plants by type of technological design used. In addition, official statistical data were analyzed.

\section{Water supply and sewerage networks}

In recent years, Poland has seen a considerable increase in investment in public utilities and sanitation infrastructure. In 2017, the water supply network was 301 thousand $\mathrm{km}$ long, with 5.6 million buildings connected to the system. Compared to 2015, the length of the water supply network increased as a result of construction of new or reconstruction of old installations, by $3.100 \mathrm{~km}$, while the number of connections to buildings increased by over 97,000. The provinces with the highest density of the water supply network were the Śląskie Voivodeship $173.3 \mathrm{~km}$ per $100 \mathrm{~km}^{2}$ (an increase of $2.6 \mathrm{~km}$ per $100 \mathrm{~km}^{2}$ compared to 2015) and the Małopolskie voivodeship $133.3\left(3.0 \mathrm{~km}\right.$ per $\left.100 \mathrm{~km}^{2}\right)$. The Zachodniopomorskie Voivodeship had the least dense water supply network at $49.0 \mathrm{~km}$ per $100 \mathrm{~km}^{2}$ (an increase of $0.5 \mathrm{~km}$ per $100 \mathrm{~km}^{2}$ ). The length of the operating water supply network in the Lubelskie Voivodeship was $84.12 \mathrm{~km}$ per $100 \mathrm{~km}^{2}$ (GUS 2017). The figures given above are a consequence of the intensity of development of the particular regions of the country, the level of their urbanization, demographic situation, and the size of commune budgets for infrastructure investment projects.

According to Central Statistical Office data and my own research, in 2016, the water supply network in Opole County was $699.9 \mathrm{~km}$ long and was $5.2 \mathrm{~km}$ longer than in 2012. The number of connections to residential buildings increased in that period by 440 pcs to 13,390 pcs. (Table 2). As new water supply networks were constructed in Opole County, new users were connected to the system. In 2016, the network served 5,281 more users than it did in 2012. Water consumption per one inhabitant had steadily increased in the years 2012-2015 to reach $28.2 \mathrm{~m}^{3}$ at the end of this period, and then dropped in the following year (2016) to $27.4 \mathrm{~m}^{3}$ (Tab. 2). Average annual water consumption per capita in the Lubelskie Voivodeship in 2016 was $28 \mathrm{~m}^{3}$. These figures show that Opole County did not differ much in water consumption from the entire Voivodeship. Currently, in Poland, there is a noticeable decrease in the amount of water consumed annually per person. Households have cut down on water use as a result of an increase in tap water prices per $1 \mathrm{~m}^{3}$ and wide-scale water metering. Additionally, water consumption rates have dropped as losses in the water supply network have been reduced due 
Table 2. Statistical data for the water supply system of Opole County (CSO 2013; 2014; 2015; 2016; 2017)

\begin{tabular}{|l|c|c|c|c|c|}
\hline \multicolumn{1}{|c|}{ Parameter } & 2012 & 2013 & 2014 & 2015 & 2016 \\
\hline Length of the water supply network [km] & 694.7 & 694.7 & 697.2 & 700.2 & 699.9 \\
\hline Number of connections to residential buildings [pcs.] & 12950 & 12982 & 13331 & 13076 & 13390 \\
\hline Volume of water supplied to households [dam ${ }^{3}$ ] & 1483.7 & 1576.5 & 1524.1 & 1726.4 & 1665.0 \\
\hline Number of users [person] & 50184 & 50819 & 55068 & 55403 & 55465 \\
\hline $\begin{array}{l}\text { Percentage of population using the water supply } \\
\text { system [\%] }\end{array}$ & 82.2 & 82.2 & 89.5 & 89.4 & 89.5 \\
\hline Water consumption per capita [m ${ }^{3}$ ] & 23.8 & 25.4 & 24.7 & 28.2 & 27.4 \\
\hline
\end{tabular}

to modernization of existing waterworks. Other factors that can affect water consumption rates include whether or not apartments have bathrooms and access to hot water, water rates in relation to domestic income, as well as the specific habits of users and their sense of social norms.

The commune with the largest water supply coverage in Opole County was the rural commune of Józefów nad Wisłą, in which a $89.8 \mathrm{~km}$ long network supplied running water to $99.6 \%$ of the population (Tab. 3). The water supply network with the smallest coverage was the one operating in Poniatowa, which had 1,590 connections and supplied water to 12,801 people $(87.7 \%$ of all residents). Other communes in which a high percentage of the population had access to a mains water supply system were Łaziska (97.2\%), Wilków (97.1\%), and Chodel (95.7\%), which is a very good result (Tab. 3). In the light of these figures, sustainable development of the investigated area requires dynamic expansion of the sanitation network as a component of public utility infrastructure complementary to the waterworks.

Water consumption differed from one commune to the next and depended primarily on the level of urbanization, as well as the lifestyle of the residents. There was no significant relationship between water supply coverage and water consumption rates. For example, users in the communes of Wilków and Łaziska, which had a $97 \%$ coverage, consumed 19.9 and $33.1 \mathrm{~m}^{3}$ of water, respectively, while the inhabitants of the commune of Chodel, which had a slightly lower coverage, used $574.8 \mathrm{~m}^{3}$ of water. These data, however, may not be objective, as they may include volumes of water used for irrigation of crops or watering of livestock. This observation seems to be confirmed by the fact that another commune with a high water consumption rate was Józefów nad Wisłą, which is an important horticulture and vegetable farming center. Low water consumption rates may also indicate that residents have their own water intakes, such as deep wells, which are still quite common in rural areas.

In 2016, the sewerage network in Poland was over 154,000 km long, with about 3.2 million connections to buildings. Compared to 2015, the length of the sewerage network increased as a result of construction of new or reconstruction of old installations by approx. 4,300 km (2.9\%) with over 152,000 new connections (a 5\% increase). $58.7 \%$ of the sewerage network and $45.3 \%$ of connections were located in rural areas. The length of the sewerage network in rural areas increased by over $2,000 \mathrm{~km} \mathrm{(3.2 \% )} \mathrm{compared} \mathrm{to}$ 2015 , with over 81,000 new connections (a $6.0 \%$ increase). In the same period, over $1,500 \mathrm{~km}$ of sewage pipes were laid in cities and towns (a

Table 3. Statistical data for the water supply system of Opole County by commune

\begin{tabular}{|c|c|c|c|c|c|}
\hline Commune & $\begin{array}{l}\text { Length of the } \\
\text { water supply } \\
\text { network [km] }\end{array}$ & $\begin{array}{l}\text { Number of } \\
\text { connections } \\
\text { to residential } \\
\text { buildings [pcs.] }\end{array}$ & $\begin{array}{l}\text { Number of users } \\
\text { [persons] }\end{array}$ & $\begin{array}{l}\text { Percentage of } \\
\text { population con- } \\
\text { nected to the } \\
\text { water supply } \\
\text { network }\end{array}$ & $\begin{array}{c}\text { Water } \\
\text { consumption per } \\
\text { inhabitant }\left[\mathrm{m}^{3}\right]\end{array}$ \\
\hline Opole Lubelskie & 157.3 & 3218 & 15668 & 89.5 & 30.4 \\
\hline Poniatowa & 86.5 & 1590 & 12800 & 87.7 & 26.5 \\
\hline Chodel & 110.0 & 1829 & 6500 & 95.7 & 574.8 \\
\hline Józefów nad Wisłą & 89.8 & 1923 & 6750 & 99.6 & 587.6 \\
\hline Karczmiska & 79.3 & 1525 & 5200 & 88.9 & 22.3 \\
\hline Łaziska & 91.4 & 1603 & 5055 & 97.2 & 33.1 \\
\hline Wilków & 85.9 & 1388 & 4500 & 97.1 & 19.9 \\
\hline
\end{tabular}


$2.5 \%$ increase) and approx. 71,000 new connections were made (a $4.2 \%$ increase). The largest increases in the total length of sewage networks compared to 2015 were recorded in the following voivodeships: Wielkopolskie $6.3 \%$ (6\% in cities), Lubuskie $4.5 \%$ (5.2\% in cities), and Mazowieckie $4.3 \%$ (2.7\% in cities), and the smallest in the Świętokrzyskie Voivodeship $1.2 \%(0.1 \%$ in cities). In 2016, the densest sewerage networks were found in the cities of two voivodeships: Śląskie $130.4 \mathrm{~km}$ per $100 \mathrm{~km}^{2}$ and Małopolskie $102.3 \mathrm{~km}$ per $100 \mathrm{~km}^{2}$. Voivodeships with the least dense urban sewerage networks included the Podlaskie Voivodeship $17.4 \mathrm{~km}$ per $100 \mathrm{~km}^{2}$ and the Lubelskie Voivodeship $25.7 \mathrm{~km}$ per $100 \mathrm{~km}^{2}$ (GUS 2016).

According to the data obtained from the surveys and the Central Statistical Office (2017), the total length of the sewerage network in Opole County in 2016 was $110.2 \mathrm{~km}$ (an increase of $20.4 \mathrm{~km}$ compared to 2012 (GUS 2013)), a figure that had not changed since 2015. Despite an increase in the number of connections (73 new connections) in 2016, the number of users increased by only three persons compared to 2015 and was 19,930 people (Tab. 4). It is also worth paying attention to the gradual decrease in the quantity of generated sewage from $1,170 \mathrm{dam}^{3}$ in 2014 to $996 \mathrm{dam}^{3}$ in 2016. The general decrease in the amount of sewage discharged to sewers in the entire County may have been caused by several factors, such as the reduction of water consumption per inhabitant (greater ecological awareness), a significant increase in water supply and sewage disposal service prices, and introduction of metering of the individual buildings.

An analysis of the data for the individual communes of Opole County shows that the provision of sanitation services in those communes is very poor. The urban commune of Poniatowa is the only one with an acceptably high sanitation coverage, with $73.3 \%$ of residents $(10,700$ people) connected to the system (Tab. 5). In this commune, new connections were added to the network at a much faster rate than new pipelines. The realization of the investments can be said to have led to the achievement of the projected ecological objectives. Łaziska was the County's only commune without a centralized sewage disposal system. Given, that the commune had a very high water supply coverage ( $97.2 \%$ ), this is a very unfavorable situation (Tab. 5). The disproportion may be a consequence of the large dispersion of residential buildings in the commune, which makes investments in the sewerage network economically unviable. In the survey, the local authorities (Commune Office) did not declare their willingness to invest in sanitation infrastructure in the following years. The fact that the sewerage network served much fewer users than the water supply system created a new type of threat to the environment, namely, relatively small, but numerous uncontrolled discharges of untreated wastewater to wasteland or to (often leaky)

Table 4. Statistical data for the sewerage network in Opole County for the years 2012-2016 (CSO 2013; 2014; $2015 ; 2016$; 2017)

\begin{tabular}{|l|c|c|c|c|c|}
\hline \multicolumn{1}{|c|}{ Parameter } & 2012 & 2013 & 2014 & 2015 & 2016 \\
\hline Length of the operating sewerage network [km] & 89.8 & 99.9 & 100.8 & 110.2 & 110.2 \\
\hline Number of connections to residential buildings [pcs.] & 1908 & 2096 & 2169 & 2239 & 2312 \\
\hline Volume of sewage discharged to sewers & 1006 & 984 & 1170 & 999 & 996 \\
\hline Number of users connected to the sewerage network [persons] & 19357 & 19798 & 19923 & 19927 & 19930 \\
\hline
\end{tabular}

Table 5. Statistical data for the sewerage network of Opole County by commune

\begin{tabular}{|c|c|c|c|c|c|}
\hline Commune & $\begin{array}{c}\text { Length of the } \\
\text { sewerage network } \\
{[\mathrm{km}]}\end{array}$ & $\begin{array}{c}\text { Number of } \\
\text { connections } \\
\text { to residential } \\
\text { buildings [pcs.] }\end{array}$ & $\begin{array}{l}\text { Number of users } \\
\text { [persons] }\end{array}$ & $\begin{array}{c}\text { Percent of } \\
\text { population } \\
\text { connected to the } \\
\text { sewerage network }\end{array}$ & $\begin{array}{c}\text { Volume of sewage } \\
\text { discharged into } \\
\text { the sewerage } \\
\left.\text { network [dam }{ }^{3}\right]\end{array}$ \\
\hline Opole Lubelskie & 25.7 & 955 & 6050 & 10 & 498 \\
\hline Poniatowa & 41.3 & 649 & 10700 & 73.3 & 411 \\
\hline Chodel & 9.7 & 236 & 860 & 12.7 & 31 \\
\hline Józefów nad Wisłą & 3.3 & 127 & 1200 & 17.7 & 26 \\
\hline Karczmiska & 29.8 & 343 & 900 & 15.4 & 29 \\
\hline Łaziska & 0 & 0 & 0 & 0 & 0 \\
\hline Wilków & 0.4 & 2 & 220 & 4.7 & 1 \\
\hline
\end{tabular}


cesspools (Piszczek and Biczkowski, 2010). Such discharges may lead to environmental devastation of large areas of land, as well as posing a sanitary and epidemiological threat. To prevent this, sewerage networks must be expanded and new wastewater treatment plants must be built.

In most communes of Opole County, there is a large disproportion between the coverage levels of the sewerage and water supply systems (Fig. 2). The lack of investment is very often associated with the lack of economic justification for the construction of sewerage networks in rural areas, many of which have a dispersed settlement pattern. Investment in sanitation infrastructure is very often held back due to environmental, social and technical concerns. The survey shows that authorities of most of the communes plan to build elements of sanitation infrastructure in the coming years. The sewerage network needs to be expanded to match the size of the water supply network and in this way meet the requirements arising from applicable legal acts, especially that there is strong social pressure for improving sanitation services.

\section{Centralized and on-site wastewater treatment plants}

At the time of the 2016 survey, Opole County had eight centralized wastewater treatment plants with a capacity of over $5 \mathrm{~m}^{3} / \mathrm{d}$. They were all biological wastewater treatment plants, and had a total capacity of $8,470 \mathrm{~m}^{3} / \mathrm{d}$. The County's largest operating treatment plants were located in the urban-rural communes of Opole Lubelskie $\left(4,278 \mathrm{~m}^{3} / \mathrm{d}\right)$ and Poniatowa $\left(3,200 \mathrm{~m}^{3} / \mathrm{d}\right)$.

Large treatment facilities with a capacity of over $100 \mathrm{~m}^{3} / \mathrm{d}$ were located in the communes of Karczmiska (454 m³/d), Józefów nad Wisłą $\left(210 \mathrm{~m}^{3} / \mathrm{d}\right)$, and Chodel $\left(150 \mathrm{~m}^{3} / \mathrm{d}\right)$. Wastewater from the commune of Łaziska was transported to the treatment plant in Opole Lubelskie, because the commune did not have its own installation (Tab. 6). The survey shows that the County's treatment facilities served $40.8 \%$ of the population.

In areas where sanitation infrastructure was poorly developed, part of the inhabitants used off-mains domestic wastewater disposal systems, which, in some circumstances, are a cheaper alternative to a centralized system. The on-site systems used included cesspools and domestic wastewater treatment plants. In 2016, 2 million 333 thousand of such installations were in use in Poland, of which about $91 \%$ were cesspools. For several years now, however, there has been a systematic decrease in the number of cesspools used, while the number of domestic wastewater treatment plants has been on an increase. The number of cesspools fell from around 2 million 136 thousand in 2015, to 2 million 117 thousand in 2016 $(0.9 \%)$, while the number of domestic wastewater treatment plants increased from around 203 thousand in 2015 to around 217 thousand in 2016 (6.8\%) (GUS 2017). Most of the on-site disposal systems (86\%) were located in rural areas: $85 \%$ of the total number of cesspools and about $92 \%$ of the total number of domestic wastewater treatment plants. The fact that a large percentage of inhabitants of areas with a dispersed development pattern dispose their wastewater into domestic wastewater treatment plants and that these installations start to have an increasingly strong impact on the quality of the environment, especially aquatic environment, poses additional challenges regarding their efficiency, which depends on good technological design, solid construction, and scrupulous maintenance. In accordance with the basic principles of sustainable development,

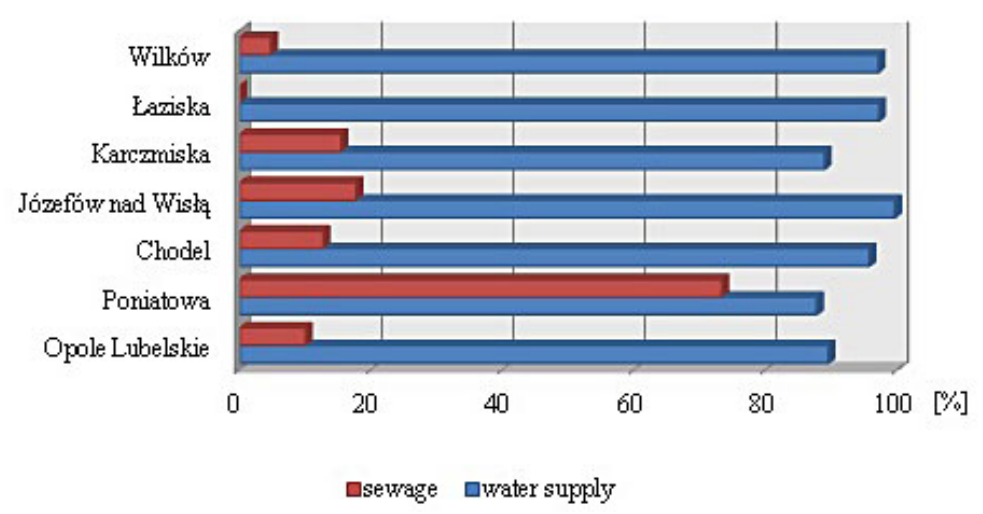

Figure 2. Percentage of residents of Opole Lubelskie District with access to the sanitary infrastructure in 2016 
Table 6. Centralized wastewater treatment plants with a capacity of more than $5 \mathrm{~m}^{3} / \mathrm{d}$ in the communes of Opole County

\begin{tabular}{|l|l|c|}
\hline \multicolumn{1}{|c|}{ Commune } & \multicolumn{1}{|c|}{ Name of treatment plant } & Capacity [m³/d] \\
\hline Opole Lubelskie & Municipal Wastewater Treatment Plant in Opole Lubelskie & 4278 \\
\hline \multirow{2}{*}{ Poniatowa } & Municipal Wastewater Treatment Plant in Poniatowa & 3200 \\
\cline { 2 - 3 } & Local Wastewater Treatment Plant in Niezabitów & 25 \\
\hline Chodel & Wastewater Treatment Plant in Chodel & 150 \\
\hline \multirow{2}{*}{ Józefów nad Wisłą } & Wastewater Treatment Plant in Kolczyn & 210 \\
\cline { 2 - 3 } & Wastewater Treatment Plant in Mazanów & 60 \\
\hline Karczmiska & Wastewater Treatment Plant in Karczmiska & 454 \\
\hline Łaziska & - & - \\
\hline Wilków & Wastewater Treatment Plant in Namysłów & 30 \\
\hline
\end{tabular}

the overriding criterion for the assessment and selection of a small (on-site) wastewater treatment plant is the ecological criterion, i.e. the plant's treatment efficiency. Other criteria include easy use and modern design (technical criteria), investment and maintenance costs (economic criteria), operational reliability (reliability criterion), and impact on the natural environment and aesthetics (environmental criteria) (Mucha and Mikosz 2009). When a very large number of on-site domestic wastewater treatment plants are planned to be built in one commune, ideally, all of these criteria should be taken into account when choosing a technological treatment option. The survey data show that Opole County had 84 on-site domestic wastewater treatment plants consisting of a septic tank and a drainfield, which is a highly undesirable technological solution. The largest number of systems with a drainfield were recorded in the communes of Karczmiska - 71, Wilków - 12, and Józefów nad Wisłą - 1 . The popularity of this option is mainly due to its low price. However, as has already been mentioned, in addition to the economic criterion, ecological considerations should also constitute a top priority in selecting wastewater treatment systems for residential buildings. Unfortunately, treatment plants with a drainfield are not highly efficient; so much so that they may be said to pose a threat to the natural environment. Numerous studies indicate that this technological solution should not be approved for widespread use. The main disadvantage of systems with a drainfield is that they do not allow to monitor the quality of treated sewage, and that they only remove mechanical impurities, discharging an effluent that may lead to the degradation of the soil and aquatic environments (Jucherski and Walczowski 2001; Jóźwiakowski et al. 2014; Pawełek and Bugajski 2017). From the environmental point of view, it is much more beneficial to use constructed wetlands, which are very efficient treatment and disposal systems (Dębska et al. 2015; Gajewska et al. 2015; Jóźwiakowski et al. 2015; Gizińska et al. 2016; Jóźwiakowski et al. 2017b; Jóźwiakowski et al. 2018; Jucherski et al. 2017).

According to the survey data, there were 6,946 cesspools in Opole County in 2016, which were used by 12,684 inhabitants. Because, the survey provides no data for the commune of Opole Lubelskie, the actual number of users was probably much higher, considering the number of operating cesspools used in that commune $(1,742$ pcs.) (Tab. 7). The data presented in table 7 indicate that Opole County is in great demand for the construction of on-site domestic wastewater treatment plants, which could become an alternative to cesspools. The fewest cesspools were found in the commune of Poniatowa (528 pcs.), which provided centralized sanitation services to the largest proportion of inhabitants among all of the County's communes (Tab. 5). The communes with the largest numbers of cesspools were Opole Lubelskie (1,742 pcs.) and Józefów nad Wisłą (1200 pcs.) (Table 7). Such a large concentration of cesspools in one area is associated with the risk of liquid impurities permeating to groundwater in aquifers and to surface waters. To avoid environmental damage, it is crucial that cesspools are regularly inspected for leakage. Numerous households in rural areas use old cesspools that are not watertight and permit sewage to pass in an uncontrolled manner to the environment. Contamination of soil and water is one of the main problems associated with the management of domestic wastewater. A leaking cesspool poses a threat not only to its users, but also to their neighbours. This is because wastewater spreads over long distances from the source, carrying pathogenic bacteria that pose a major threat to the environment (Zadroga et al. 2001). 
Table 7. Cesspools in Opole County (author's own table)

\begin{tabular}{|l|c|c|c|c|}
\hline \multicolumn{1}{|c|}{ Commune } & Cesspools in use [pcs.] & $\begin{array}{c}\text { Cesspools out of use } \\
\text { [pcs.] }\end{array}$ & $\begin{array}{c}\text { Cesspools with an } \\
\text { emptying contract [pcs.] }\end{array}$ & $\begin{array}{c}\text { Number of cesspool } \\
\text { users [persons] }\end{array}$ \\
\hline Opole Lubelskie & 1742 & nd & nd & nd \\
\hline Poniatowa & 528 & 0 & 528 & 2400 \\
\hline Chodel & 810 & 0 & 0 & 5550 \\
\hline Józefów nad Wisłą & 1200 & 200 & 214 & 3299 \\
\hline Karczmiska & 952 & 9 & 893 & 0 \\
\hline Łaziska & 864 & 0 & 0 & 660 \\
\hline Wilków & 850 & 10 & 30 & \\
\hline
\end{tabular}

\section{CONCLUSIONS}

1. In Opole County, there is a huge disproportion between the numbers of users connected to the water supply and sewerage systems. On average, $89.5 \%$ of the County's inhabitants have access to a mains water supply system, but only $32.8 \%$ are connected to a centralized sewerage network. To compare, in 2016 on average $70 \%$ of the Polish population had access to a centralized sewage disposal system. To reach this level, Opole County must invest more heavily in expanding its sanitation infrastructure.

2. The disproportion between the two types of utility networks in Opole County is growing larger as the water supply system is being expanded at a much faster rate than the sewerage system. The percent water supply coverage for the individual communes ranges between 88.9-99.6\%, while the sanitation coverage level for most of the communes does not exceed $20 \%$.

3. The urban commune of Poniatowa is the County's only commune where the disproportion between the discussed networks is only slight, with $87.7 \%$ of the population having access to running water and $73.3 \%$ to sanitation services.

4. In 2016, the County had eight centralized wastewater treatment plants with a total capacity of approximately $8,470 \mathrm{~m}^{3} \cdot \mathrm{d}^{-1}$.

5. According to the 2016 survey, Opole County had 6,946 cesspools. The largest number of them were found in the communes of Opole Lubelskie (1,742 pcs.) and Józefów nad Wisłą $(1,200$ pcs.). The number of cesspools used was closely related to the sewerage system coverage in those communes.

6. The on-site domestic wastewater treatment plants in Opole County are almost exclusively systems with a drainfield, which may pose a serious threat to the soil and water environments. There is a huge demand for the construction of efficient on-site domestic wastewater treatment plants, which could replace the existing (often leaky) cesspools, especially in areas with a highly dispersed development pattern.

7. Local governments should take measures to expand the sewerage network, replace cesspools, and build highly efficient on-site domestic wastewater treatment plants.

\section{REFERENCES}

1. Bogusz M., Marzec M., Malik A., Jóźwiakowski K., 2020. The state and needs of the development of water supply and sewerage infrastructure in the Radzyń District. Journal of Ecological Engineering 21(3), 171-179.

2. Bugajski P., Gajewska M., Jóźwiakowski K., Siwiec T., 2017. Rozwiązania technologiczne stosowane w gospodarce wodno-ściekowej na terenach wiejskich. (In:) Jóźwiakowski K., Siuda W. (Eds.) Ochrona i kształtowanie zasobów wodnych na terenach wiejskich. Fundacja na rzecz Rozwoju Polskiego Rolnictwa. Warszawa, 55-70.

3. Chmielowski K., 2016. Zagadnienia prawne związane z POŚ. Part I. Przegląd Komunalny, 2, 58-60.

4. Dębska A., Jóźwiakowski K., Gizińska-Górna M., Pytka A., Marzec M., Sosnowska B., Pieńko A., 2015. The efficiency of pollution removal from domestic wastewater in constructed wetland systems with vertical flow with Common reed and Glyceria maxima. Journal of Ecological Engineering 16(5), $110-118$.

5. Dz.U. $2001 \mathrm{nr} 115$ poz. 1229 Ustawa z dnia 18 lipca 2001 r. - Prawo wodne (tekst jednolity) (Journal of Laws of the Republic of Poland 2001 No. 115 item 1229 Act of 18 July 2001 - Water Law (consolidated text)). Dz.U. z 2015 r., poz. 469 (ze zm.) (Journal of Laws of the Republic of Poland of 2015, item 469, (with later amendments).

6. Dz.U. 2016 poz. 1911 Rozporządzenie Rady Ministrów z dnia 18 października 2016 r. w sprawie Planu gospodarowania wodamina obszarze dorzecza Wisły (Journal of Laws of the Republic of Poland 2016 item 1911 Regulation of the Council of Ministers of October 18, 2016 regarding the Vistula River Basin Management Plan). 
7. Gajewska M., Jóźwiakowski K., Ghrabi A., Masi F., 2015. Impact of influent wastewater quality on nitrogen removal rates in multistage treatment wetlands. Environ. Sci. Pollut. Res. 22, 12840-1284.

8. Gizińska-Górna M., Czekała W., Jóźwiakowski K., Lewicki A., Dach J., Marzec M., Pytka A., Janczak D., Kowalczyk-Juśko A., Listosz A., 2016. The possibility of using plants from hybrid constructed wetland wastewater treatment plants for energy purposes. Ecological Engineering 95, 534-541.

9. GUS (Central Statistical Office) 2017. Infrastruktura komunalna w 2016 roku.

10. Jóźwiakowski K., 2003. Analiza efektów oczyszczania ścieków bytowych w oczyszczalniach przydomowych na terenach wiejskich na przykładzie wybranych obiektów w województwie lubelskim. Acta Scientiarum Polonorum, ser. Formatio Circumiectus, 2(1), 3-14.

11. Jóźwiakowski K., 2012. Przydomowe oczyszczalnie ścieków na terenach wiejskich - Part I. Inżynier budownictwa, 10, 57-60.

12. Jóźwiakowski K., Bugajski P., Kurek K., Nunes de Carvalho M. F, Araújo Almeida M. A., Siwiec T., Borowski G., Czekała W., Dach J., Gajewska M., 2018. The efficiency and technological reliability of biogenic compounds removal during long-term operation of a one-stage subsurface horizontal flow constructed wetland. Separation and Purification Technology, 202, 216-226.

13. Jóźwiakowski K., Bugajski P., Mucha Z., Wójcik W., Jucherski A., Natawny M. Siwiec T., Mazur A., Obroślak R., Gajewska M., 2017b. Reliability of pollutions removal processes during long-term operation of one-stage constructed wetland with horizontal flow. Separation and Purification Technology, 187, 60-66.

14. Jóźwiakowski K., Podbrożna D., Kopczacka K., Jaguś M., Marzec M., Listosz A., Pochwatka P., Kowalczyk-Juśko A., 2018. The state of water and wastewater management in the municipalities of the Roztocze National Park. Journal of Ecological Engineering, 19.

15. Jóźwiakowski K., Podbrożna D., Kopczacka K., Marzec M., Kowalczyk-Juśko A., Pochwatka P., Listosz A., Malik A., 2017. The state of water and wastewater management in the municipalities of the Polesie National Park. Journal of Ecological Engineering, 18 (6), 192-199.

16. Jóźwiakowski K., Steszuk A., Pieńko A., Marzec M., Pytka A., Gizińska M., Sosnowska B., Ozonek J., 2014. Evaluation of the impact of wastewater treatment plants with drainage system on the quality of groundwater in dug and deep wells. Inżynieria Ekologiczna, 39, 74-84 (in Polish).

17. Jucherski A., Nastawny M., Walczowski A., Jóźwiakowski K., Gajewska M., 2017. Assessment of the technological reliability of a hybrid constructed wetland for wastewater treatment in a mountain eco-tourist farm in Poland. Water Sci. Technol. 75 (11), 2649-2658.

18. Jucherski A., Walczowski A., 2001. Drainage systems. Cleaning or discharging untreated sewage into the soil. Wiadomości Melioracyjne i Łąkarskie 3 (390), 131-132 (in Polish).

19. Jucherski A., Walczowski A., 2001. Drenaże rozsączające. Oczyszczanie czy odprowadzanie nieoczyszczonych ścieków do gleby? Wiad. Melior. Łąk., 3(390), 131-132.

20. Karolinczak B., Miłaszewski R., Sztuk A., 2015. Cost-effectiveness analysis of different technological variants of single-house sewage treatment plants. Rocznik Ochrona Środowiska, 17, 726-746 (in Polish).

21. Micek A., Marzec M., Jóźwiakowska K., Pochwatka P., 2018. The Condition of Sanitary Infrastructure in the Parczew District and the need for its development. Journal of Ecological Engineering, 19(5), 107-115,

22. Milczarek M., Walkowiak K., Smakulski J., 2016. Aktualizacja Programu Ochrony Środowiska dla Powiatu Opolskiego na lata 2017-2020 z perspektywą do roku 2024.

23. Mucha Z., Mikosz J., 2009. Racjonalne stosowanie małych oczyszczalni ścieków z uwzględnieniem kryteriów zrównoważonego rozwoju, ,Czasopismo Techniczne. Środowisko" Wyd. Politechniki Krakowskiej, Iss. 2-ŚS.

24. Obarska-Pempkowiak H., Kołecka K., Gajewska M., Wojciechowska E., Ostojski A., 2015. Zrównoważone gospodarowanie ściekami na przykładzie obszarów wiejskich. Rocz. Ochr. Środ., 17, 585-602.

25. Pawełek J., 2016. Degree of development and functionality of the water supply and sewage systems in rural Poland. Barometr Regionalny, 14(1), 141-149.

26. Pawełek J., Bugajski P., 2017. The development of household wastewater treatment plants in Poland - advantages and disadvantages. Acta Scientiarum Polonorum, Formatio Circumiectus, 16(2), 3-14 (in Polish).

27. Piszczek S., Biczkowski M., 2010. Infrastruktura komunalna jako element planowania i kształtowania rozwoju obszarów wiejskich ze szczególnym uwzględnieniem terenów chronionych (w:) Infrastruktura i ekologia terenów wiejskich, Kraków.

28. Walczowski A., 2013. Przydomowe oczyszczalnie ścieków dla zrównoważonego rozwoju terenów wiejskich. (In:) Polski Klub Ekologiczny Koło Miejskie w Gliwicach. Technologie i urządzenia w zakresie przydomowych oczyszczalni ścieków, Gliwice.

29. www.portalgospodarczy.eurzad.eu

30. Zadroga B., Olańczuk-Neyman K., 2001. Ochrona i rekultywacja podłoża gruntowego. Gdańsk: Wydawnictwo PGdań, 226. 